\title{
Catatan Penelitian \\ Kandungan Lemak, Tekstur Kemasiran dan Kesukaan Telur Asin dengan Penambahan Jahe sebagai Penyedap Rasa
}

\section{Fat Content, Grittiness Texture and Preferences of Salted Eggs Added with Ginger as Flavoring}

Luthfi Hakim, Valentinus Priyo Bintoro, Bambang Dwiloka

Program Studi S-1 Teknologi Pangan, Jurusan Pertanian, Fakultas Peternakan dan Pertanian, Universitas Diponegoro, Semarang

*Korespondensi dengan penulis (bdl_consulting@yahoo.com)

Artikel ini dikirim pada tanggal 10 Desember 2016 dan dinyatakan diterima tanggal 21 Juni 2017. Artikel ini juga dipublikasi secara online melalui www.jatp.ift.or.id. Hak cipta dilindungi undang-undang. Dilarang diperbanyak untuk tujuan komersial.

Diproduksi oleh Indonesian Food Technologists® (C2017

\begin{abstract}
Abstrak
Penelitian ini dilakukan untuk mengetahui adanya perbedaan kadar lemak, nilai kemasiran dan kesukaan telur asin dengan penambahan berbagai konsentrasi jahe gajah halus (JGH). Rancangan percobaan yang digunakan pada penelitian ini yaitu Rancangan Acak Lengkap (RAL) dengan 5 perlakuan dan 4 ulangan. Perlakuan yang diterapkan pada penelitian ini adalah konsentrasi penambahan JGH: T0 tanpa JGH; T1: konsentrasi JGH 15\%; T2: konsentrasi JGH 30\%; T3: konsentrasi JGH 45\%; dan T4: konsentrasi JGH 60\%. Parameter pengamatan pada penelitian ini adalah kadar lemak telur asin, dan organoleptik tekstur kemasiran dan kesukaan. Hasil penelitian menunjukkan bahwa penambahan berbagai konsentrasi JGH pada telur itik yang diasinkan memberikan perbedaan nyata $(p<0,05)$ pada kadar lemak, sedangkan tekstur kemasiran dan kesukaan pada telur asin tidak memberikan pengaruh ( $p>0,05)$. Kadar lemak terendah dihasilkan T3 sebesar 13,60\% dan tertinggi dihasilkan T0 sebesar 17,89. Nilai tekstur kemasiran dihasilkan T0; T1; T2; T3; dan T4 agak masir, dan kesukan pada telur asin dihasilkan suka sampai agak suka. Pembuatan telur asin dengan metode perendaman menggunakan larutan garam jenuh sebaiknya direndam lebih dari 7 hari.
\end{abstract}

Kata Kunci: telur asin, konsentrasi jahe, larutan garam

\section{Abstract}

This study was conducted to determine the fat content grittiness texture differences and preferences of the salted eggs added with various concentrations of grinded ginger (JGH). The experimental design used in this study was completely randomized design (CRD) with 5 treatments and 4 replications. The treatment used in this study ware the concentrations of the JGH addition: TO= without $J G H ; T 1=J G H$ concentration of $15 \%$; T2= JGH concentration of 30\%; T3= JGH concentration of 45\%; and T4= JGH concentration of $60 \%$. Variable observation in this study is the fat content of salted eggs, and organoleptic grittines texture and preference of salted egg. The results showed that the addition of various concentrations of JGH in salted egg had significant ( $p<0.05)$ on the parameters measured levels of fat, while the organoleptic test grittines texture and a preferences for salted eggs did not influence significantly different ( $p>0.05$ ). The lowest fat content was T3 of $13.60 \%$, and the highest result enough was T0 of 17.89. Organoleptic grittines texture generated T0; T1; T2; T3; and T4 somewhat grittin, and preferences on salted eggs produced like to rather like. Making salted eggs with immersion method using a saturated salt solution should be soaked longer than 7 days.

Keywords: salted egg, gingger concentration, salt solution

\section{Pendahuluan}

Telur merupakan bahan pangan hewani yang mempunyai kandungan gizi lengkap salah satunya yaitu sebagai sumber protein yang tinggi, mudah dicerna dan memiliki rasa lezat (Agustina, 2013). Selain hal tersebut, telur juga mudah didapatkan dengan harga yang terjangkau sehingga masyarakat banyak yang menyukai telur.

Masyarakat pada umumnya mengolah telur dengan menggoreng, merebus, menjadikan sebagai bahan campuran dalam pembuatan kue, sebagai campuran minuman obat kuat, dan telur asin. Pengasinan pada telur merupakan salah satu upaya untuk mempertahankan kualitas telur. Telur yang telah diasinkan mempunyai daya simpan yang cukup lama dan memiliki cita rasa yang khas (Yuniati, 2012). Penambahan garam dalam jumlah tertentu pada suatu bahan pangan dapat mengawetkan bahan pangan tersebut.

Seiring perkembangan jaman, sekarang masyarakat membutuhkan olahan telur asin dengan penambahan rasa, sehingga masyarakat dapat memilih rasa yang diinginkan. Penambahan rasa tersebut dapat memperkaya olahan produk berbasis telur yang beredar, salah satu penambahan rasa pada telur yang menyatu dan sudah tidak asing pada masyarakat yaitu dengan penambahan jahe, karena kebanyakan masakan olahan juga ditambahkan jahe. Menurut Koswara et al. (2012) rimpang jahe dapat digunakan sebagai bumbu masakan, pemberi aroma, dan rasa pedas pada makanan, misalnya roti, kue, biskuit, dan berbagai minuman.

Jahe (Zingiber officinale Roscoe) merupakan rempah-rempah Indonesia yang sangat penting dalam kehidupan sehari-hari, terutama dalam bidang kesehatan. Jahe merupakan tanaman obat berupa tumbuhan rumpun berbatang semu dan termasuk dalam suku temu-temuan (Zingiberaceae). Jahe berasal dari Asia Pasifik yang tersebar dari India sampai Cina (Paimin, 2008).

Tujuan penelitian ini adalah untuk mengetahui pengaruh penambahan jahe terhadap kandungan 
lemak, kemasiran dan kesukaan telur asin, dan mencari persentase yang optimal jahe yang ditambahkan dalam proses pengasinan telur dalam kaitannya dengan beberapa parameter tersebut.

Manfaat yang diperoleh dari penelitian ini adalah dapat memperkaya diversifikasi pangan yang berasal dari bahan baku lokal dan bermanfaat bagi kesehatan, karena dengan penambahan jahe dapat berpotensi sebagai pangan fungsional. Adanya penganeka ragaman jenis olahan telur asin dapat memberikan pilihan bagi konsumen sehingga tidak hanya dengan olahan telur asin saja tetapi adanya penambahan rasa jahe.

\section{Materi dan Metode \\ Materi}

Bahan yang digunakan dalam pembuatan telur asin adalah telur itik umur sehari dari Satuan Kerja Balai Pembibitan dan Budidaya Ternak Itik Banyubiru, Salatiga. Jahe gajah diperoleh dari Pasar Banyumanik Semarang. Bahan lain adalah aquades, dan garam dapur. Bahan yang digunakan uji kadar lemak adalah pelarut dietil eter atau petroleum eter.

Alat yang digunakan dalam pembuatan telur asin adalah toples plastik tertutup, timbangan, blender, gelas ukur, panci, dan kompor. Alat-alat yang digunakan untuk uji sensoris menggunakan seperangkat alat uji sensori. Alat untuk pengujian kadar lemak yang digunakan adalah kertas saring, labu lemak dan alat soxhlet, pemanas listrik, oven, timbangan, kapas bebas lemak, desikator, dan tang penjepit.

\section{Metode}

Metode penelitian meliputi rancangan penelitian, prosedur penelitian, uji parameter, dan analisis data.

\section{Rancangan Penelitian}

Penelitian ini menggunakan Rancangan Acak Lengkap (RAL) dengan perlakuan penambahan jahe gajah halus (JGH), yaitu (T0) tanpa penambahan JGH yang digunakan sebagai kontrol; (T1) penambahan JGH 15\%; (T2) penambahan JGH 30\%; (T3) penambahan JGH 45\%; dan (T4) penambahan JGH $60 \%$. Setiap perlakuan diulang sebanyak 4 kali sehingga terdapat $5 \times 4=20$ satuan percobaan.

\section{Prosedur Penelitian}

Penyiapan Telur Itik

Bahan yang digunakan dalam penelitian ini adalah telur itik yang di ambil dari satuan kerja Balai Pembibitan dan Budidaya Ternak Itik Banyubiru, Salatiga yang berumur satu hari dengan berat antara $60 \mathrm{~g}$ sampai $65 \mathrm{~g}$ dan memiliki mutu yang baik, yaitu bila dimasukkan kedalam air telur akan tenggelam hingga menyentuh dasar wadah sesuai dengan pendapat Suprapti (2002) bahwa keadaan telur yang melayang atau terapung apabila di letakkan dalam air sudah tidak baik untuk dikonsumsi, kemudian telur dicuci hingga bersih sehingga tidak ada kotoran yang menempel pada cangkang telur yang dapat mengkontaminasi telur saat pembuatan telur asin.

Penyiapan Jahe Gajah Halus (JGH)
Proses penyiapan JGH yaitu jahe dicuci hingga bersih sehingga tidak ada kotoran tanah yang menempel pada permukaan jahe, kemudian pembakaran dilakukan pada jahe untuk memunculkan aroma khas pada jahe, lalu kupas kulit jahe dan dihaluskan menggunakan blender tanpa penambahan air.

\section{Penyiapan Larutan Garam Jenuh \\ Proses yang digunakan dalam pembuatan} larutan garam jenuh yaitu dengan pencampuran aquades sebanyak 5 liter dilarutkan dengan garam hingga larutan menjadi jenuh. (perbandingan takaran garam : air yaitu $2: 5$ ).

\section{Pembuatan Telur Asin Jahe}

Proses yang digunakan dalam pembuatan telur asin jahe pada penelitian ini adalah Sejumlah JGH dimasukkan kedalam larutan garam jenuh dengan penambahan 15\%, 30\%, 45\% dan $60 \%$ dari jumlah larutan tersebut. Kemudian telur itik yang sudah bersih dimasukkan dalam campuran larutan tersebut, dieram selama 7 hari pada suhu kamar dalam toples plastik yang tertutup agar garam dan jahe tersebut dapat meresap dengan baik.

\section{Uji Parameter \\ Uji Lemak}

Pengujian lemak dengan menggunakan metode ekstraksi soxhlet, dengan prinsip lemak dapat diekstraksi dengan menggunakan eter atau zat pelarut lemak lain. Jika zat pelarutnya diuapkan maka akan tertinggal lemaknya (Legowo et al., 2005).

\section{Uji Kemasiran}

Untuk mengetahui tingkat kemasiran tersebut salah satu nya yaitu dengan menganalisis secara penginderaan, analisis secara penginderaan menggunakan alat indera manusia (Wijayanti, 2007). Skala uji hedonik mulai dari tidak masir (1); agak masir (2); masir (3); dan sangat masir (4).

\section{Uji Kesukaan}

Soekarto (1985) dalam Lukito (2012) mengatakan bahwa dalam uji kesukaan, panelis diminta tanggapan pribadi tentang suka atau tidaknya dan juga menunjukkan tingkat kesukaannya, uji kesukaan merupakaan hal yang berkaitan langsung nantinya dengan daya terima oleh konsumen dengan produk tersebut. Skala uji hedonik mulai dari tidak suka (1); agak suka (2); suka (3); dan sangat suka (4).

\section{Analisis Data}

Data hasil uji kadar lemak dianalisis dengan Anova (Analysis Of Variance) pada taraf signifikan 5\%, Selanjutnya apabila data yang dihasilkan beda nyata maka dilanjutkan dengan uji wilayah ganda Duncan. Data hasil uji organoleptik kemasiran dan kesukaan ditabulasi dan dilakukan uji normalitas data dengan uji Kolmogorov-Smirnov. apabila data sudah normal maka dilanjutkan dengan uji non parametric yaitu Kruskal Wallis dengan taraf signifikan $5 \%$. 
Tabel 1. Kadar Lemak Telur Asin dengan Penambahan JGH pada Berbagai Konsentrasi

\begin{tabular}{cc}
\hline Perlakuan & $\begin{array}{c}\text { Rerata kadar Lemak } \\
(\%)\end{array}$ \\
\hline T0 & $(17,89 \pm 1,48)^{\mathrm{a}}$ \\
T1 & $(14,64 \pm 2,57)^{\mathrm{b}}$ \\
T2 & $(14,51 \pm 0,80)^{\mathrm{b}}$ \\
T3 & $(13,60 \pm 2,23)^{\mathrm{b}}$ \\
T4 & $(15,02 \pm 1,21)^{\mathrm{b}}$ \\
\hline
\end{tabular}

Keterangan: Superskrip dengan huruf yang sama pada kolom rerata menunjukkan tidak berbeda nyata $(\mathrm{p}<0,05)$. T0: tanpa penambahan JGH; T1: penambahan JGH 15\%; T2: penambahan JGH 30\%; T3: penambahan JGH 45\%; dan T4: penambahan JGH $60 \%$.

\section{Hasil dan Pembahasan}

Kadar Lemak Telur Asin dengan Penambahan JGH Hasil pengujian telur asin dengan penambahan JGH terhadap kadar lemak tersebut pada setiap perlakuan penambahan $0 \%$; $15 \%$; $30 \%$; $45 \%$; dan $60 \%$ menunjukkan adanya pengaruh nyata terhadap penurunan kadar lemak $(p<0,05)$, hal tersebut tersaji pada Tabel 1.

Hasil pengujian dalam pembuatan telur asin dengan penambahan JGH bahwa perlakuan T0 (kontrol) berbeda dengan semua perlakuan mulai dari T1; T2; T3; dan T4 hal tersebut menunjukkan bahwa penambahan JGH dapat menurunkan kadar lemak pada telur. Namun pada semua perlakuan penambahan JGH penurunan kadar lemak tersebut tidak signifikan.

Penambahan jahe segar pada pembuatan telur asin dengan cara menghancurkan jahe terlebih dahulu, kandungan jahe tersebut diharapkan masih ada dan masih lengkap kandungannya. Hal ini sesuai dengan pendapat Supriyanto dan Cahyono (2012) yang menyatakan bahwa kandungan pada jahe segar lebih lengkap dibandingkan dengan komposisi kimia pada simplisia kering. Salah satu komposisi kimia pada jahe yang dominan adalah kandungan antioksidan yang dapat menangkap radikal bebas dengan mengurangi, menahan dan mencegah proses oksidasi.

Hal ini didukung oleh pendapat Irawan dan Septiana (2012) dalam Faiz et al. (2013) yang menyatakan bahwa penggunaan tanaman obat temulawak dan jahe pada larutan pengasinan mampu meningkatkan aktivitas enzim lipase karena kandungan antioksidan pada jahe yang cukup tinggi. Aktivitas enzim lipase mampu membuat kadar lemak pada telur asin menurun, dimana mayoritas lemak pada kuning telur adalah kolesterol.

Ganesan et al. (2014) menyatakan bahwa, proses pengasinan telur dapat meningkatkan kadar lemak, hal ini terjadi karena adanya penambahan garam pada proses tersebut, lemak yang terdapat dalam telur adalah trigliserida (lemak netral), fosfolipida (lecithin), dan kolesterol, kebanyakan masyarakat menghindari asam lemak tersebut.

\section{Pengaruh Penambahan JGH terhadap Tingkat \\ Kemasiran Telur Asin}

Hasil sidik ragam menunjukkan tidak adanya pengaruh yang nyata $(P>0,05)$ dari perlakuan penambahan jahe pada berbagai konsentrasi terhadap kemasiran telur asin yang dihasilkan. hal tersebut tersaji pada Tabel 2.

Hasil yang diperoleh tersebut menunjukkan bahwa penambahan JGH sampai dengan konsentrasi $60 \%$ tidak berpengaruh pada kemasiran telur asin. Lama pemeraman dalam pembuatan telur asin ini dengan waktu pemeraman selama 7 hari dalam tabung keadaan tertutup dengan menggunakan metode larutan garam pekat. Chi dan Tseng (1998) menyatakan, bahwa terjadinya proses kuning telur memiliki tekstur masir yang dipengaruhi oleh adanya proses garam yang masuk bersama air (larutan garam) ke dalam granul-granul yang berada dalam kuning telur karena kemampuan $\mathrm{NaCl}$ yang dapat mengikat air pada protein kuning telur, sehingga kandungan air tersebut akan keluar dan mengalami dehidrasi pada kuning telur serta muncul tekstur berpasir.

Menurut Sahara (2011) dan Dang et al. (2014) faktor kemasiran pada kuning telur juga dipengaruhi oleh keberadaan kadar lemak dan $\mathrm{NaCl}$, adanya penambahan elektrolit seperti $\mathrm{NaCl}$ dan pemanasan akan mengganggu keseimbangan antar fase, yaitu fase polar (protein) dan fase non polar (lemak) sehingga fase non polar (lemak) tersebut mengeluarkan sifat minyaknya (oily) pada permukaan.

Proses pemasakan juga dapat mempengaruhi hasil telur asin yang diperoleh, menurut Nurhidayati et al. (2013) pemasakan dan kombinasi rebus dengan oven memilliki tekstur kemasiran yang lebih tinggi sehingga kadar air yang terkandung dalam kuning telur lebih rendah karena pemasakan menggunakan oven dapat mengurangi kadar air dalam kuning telur.

Tabel 2. Tekstur Kemasiran Telur Asin dengan Penambahan JGH pada Berbagai Konsentrasi

\begin{tabular}{ccc}
\hline Perlakuan & Skor Rata-Rata & Kriteria \\
\hline T0 & $(2,37 \pm 0,65)^{\mathrm{a}}$ & Agak masir \\
T1 & $(2,65 \pm 0,74)^{\mathrm{a}}$ & Agak masir \\
T2 & $(2,61 \pm 0,83)^{\mathrm{a}}$ & Agak masir \\
T3 & $(2,73 \pm 0,68)^{\mathrm{a}}$ & Agak masir \\
T4 & $(2,59 \pm 0,61)^{\mathrm{a}}$ & Agak masir \\
\hline
\end{tabular}

Keterangan: Superskirp dengan huruf sama pada kolom rerarta menunjukkan tidak berbeda nyata $(p>0,05)$. T0: tanpa penambahan JGH; T1: penambahan JGH 15\%; T2: penambahan JGH 30\%; T3: penambahan JGH 45\%; dan T4: penambahan JGH 60\%. 
Tabel 3. Kesukaan Telur Asin dengan Penambahan JGH pada Berbagai Konsentrasi

\begin{tabular}{ccc}
\hline Perlakuan & Skor Rata-Rata & Kriteria \\
\hline T0 & $(3,00 \pm 0,60)^{a}$ & Suka \\
T1 & $(2,66 \pm 0,46)^{a}$ & Agak suka \\
T2 & $(2,62 \pm 0,66)^{a}$ & Agak suka \\
T3 & $(2,66 \pm 0,73)^{a}$ & Agak suka \\
T4 & $(2,41 \pm 0,81)^{a}$ & Agak suka \\
\hline
\end{tabular}

Keterangan: Superskrip dengan huruf yang sama pada kolom rerata menunjukkan tidak berbeda nyata ( $>00,05)$. T0: tanpa penambahan JGH; T1: penambahan JGH 15\%; T2: penambahan JGH 30\%; T3: penambahan JGH 45\%; dan T4: penambahan JGH $60 \%$.

\section{Pengaruh Penambahan JGH terhadap Tingkat Kesukaan Telur Asin}

Hasil sidik ragam menunjukkan tidak adanya pengaruh yang nyata $(P>0,05)$ dari perlakuan penambahan jahe pada berbagai konsentrasi terhadap kesukaan telur asin yang dihasilkan. hal tersebut tersaji pada Tabel 3.

Berdasarkan hasil uji hedonik kesukaan pada telur asin yang diberi berbagai perlakuan yaitu dengan penambahan konsentrasi JGH yang berbeda $0 \% ; 15 \%$; $30 \%$; $45 \%$; dan $60 \%$ pada tabel tersebut menunjukkan bahwa pada setiap perlakuan tidak memberikan pengaruh nyata $(p<0,05)$ pada daya terima konsumen terhadap telur asin dengan penambahan konsentrasi jahe yang berbeda. Hal tersebut menunjukkan bahwa dengan penambahan rasa jahe sampai $60 \%$ pada telur asin masih di terima oleh konsumen dan tidak mempengaruhi kesukaan pada telur asin rasa jahe yang masih sangat jarang dijumpai oleh masyarakat pada umumnya. Menurut Tan et al. (2012) bahwa waktu perendaman telur dapat mempengaruhi sensoris yaitu tekstur, warna dan flavor dari telur asin yang baik sehingga lebih disukai konsumen.

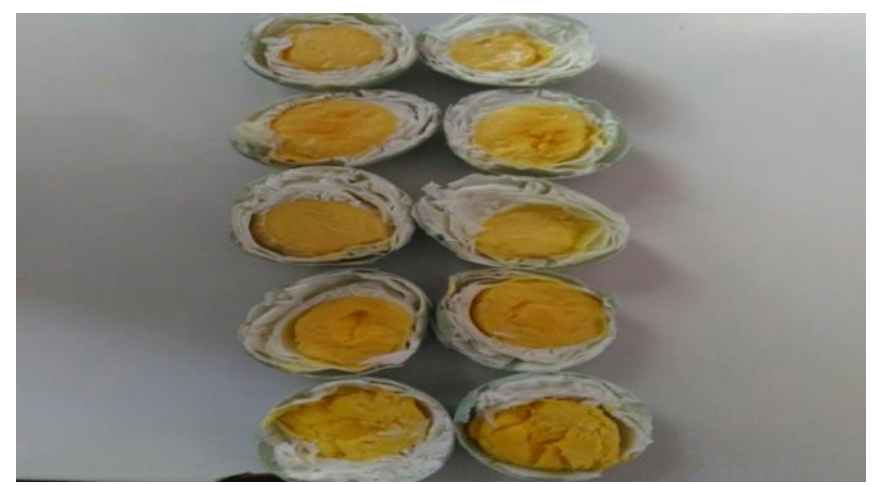

Gambar 1. Foto Kuning Telur Asin pada penambahan berbagai Konsentrasi JGH yang berbeda

Pemanfaatan jahe pada kehidupan sehari-hari sudah banyak di aplikasikan terhadap suatu bahan pangan, sehingga panelis dalam penilaian telur asin dengan penambahan jahe yang berbeda konsentrasi masih menerima. Menurut Koswara et al. (2012) bahwa keberadaaan jahe dapat dimanfaatkan sebagai bahan tambahan bumbu masakan, pemberi aroma khas jahe, dan rasa pedas dari sifat fenol merupakan bagian dari oleoresin jahe pada makanan, misalnya roti, kue, biskuit, dan berbagai minuman yang dapat menghangatkan tubuh.

\section{Kesimpulan}

Telur asin dengan penambahan JGH pada berbagai konsentrasi dapat menurunkan kadar lemak, hasil tertinggi kadar lemak pada T0 (kontrol) yaitu $17,89 \%$ dan terendah pada T3 yaitu 13,60\%. Namun pada uji organoleptik pengukuran kemasiran dan kesukaan pada telur asin dengan penambahan JGH sampai dengan $60 \%$ ini tidak mempengaruhi.

\section{Daftar Pustaka}

Agustina, N., Thohari, I., Rosyidi, D. 2013. Evaluasi sifat putih telur ayam pasteurisasi ditinjau dari $\mathrm{pH}$, kadar air, sifat dan daya kembang angel cake. Jurnal IImu-IImu Peternakan, 23 (2), 6-13.

Chi, P.S., Tseng, H.K. 1998. Physicochemical Properties of Salted Pickled Yolks From Duck and Chicken Eggs. Journal Of Food Science. 63 (1).

Dang, K.L.M., Quoc, T.L., Songsermpong, S. 2014. Effect of ultrasound treatment in the mass transfer and physical properties of salted duck eggs. Kasetsart Journal, 48, 942-953.

Faiz, H., Thohari, I., Purwadi. 2013. Pengaruh penambahan sari temulawak (Curcuma xanthorrhiza) terhadap total fenol, kadar garam, kadar lemak dan tekstur telur asin. Jurnal IImuIImu Peternakan, 24(3), 38-44

Ganesan, P., Kaewmanee, T., Benjakul, S., Baharin, B.S. 2014. Coparative study on the nutritional value of pidan and salted duck egg. Korean Journal Food sci., 34(1), 1-6.

Irawan, B. dan Septiana, S. 2012. Efek komposisi tanah dan biofarmaka terhadap penurunan kadar kolesterol pada pengasinan telur itik Albio. Agroscientiae, 19(2), 0854-2333.

Koswara, S., Diniari, A., Sumarto. 2012. Panduan Proses Produksi Minuman Jahe Instan. SEAFAST Center, Bogor.

Legowo, A.M., Nurwantoro, Sutaryo. 2005. Analisis Pangan. Badan Penerbit Universitas Diponegoro, Semarang.

Lukito, G.A., Suwarastuti A., Hintono, A. 2012. Pengaruh berbagai metode pengasinan terhadap kadar $\mathrm{NaCl}$, kekenyalandan tingkat kesukaan konsumen pada telur puyuh asin. Animal Agriculture Journal, 1(1), 829-838.

Nurhidayati, Y., Sumarmono, J., Wasito, S. 2013. Kadar air, kemasiran dan tekstur telur asin ayam niaga yang dimasak dengan cara berbeda. Jurnal Ilmiah Peternakan, 1(3), 813-820.

Paimin, F.B., Murhanato, 2008. Budidaya, Pengelolaan, Perdagangan Jahe. Penebar Swadaya: Jakarta.

Sahara, E., 2011. Penggunaan kepala udang sebagai sumber pigmen dan kitin dalam pakan ternak. Agrinak. 1 (1). 
Soekarto, S.T. 1985. Penilaian Organoleptik. Bhatara Karya Aksara, Semarang.

Suprapti, M.L. 2002. Pengawetan Telur. Kanisius, Yogyakata.

Supriyanto, Cahyono, B. 2012. Perbandingan Kandungan Minyak Atsiri Antara Jahe Segar dan Jahe Kering. Chemistry Progress, 5(2), 81-85.

Tan, Q.L.P., Hoang, O.N.T.T., Thanh, T.N.T. 2012. Some factors influencing the quality of salted quail eggs. Asian Journal of Food and AgroIndustry, 5(5), 440-447
Wijayanti, Y.R., 2007. Substitusi Tepung Gandum (Triticum aestivum) Dengan Tepung Garut (Maranta arundinaceae L) Pada Pembuatan Roti Tawar. Skripsi. Universitas Gajah Mada, Yogyakarta.

Yuniati, H., Almasyhuri. 2012. Pengaruh perbedaan media dan waktu pengasinan pada pembuatan telur asin terhadap kandungan iodium telur. Pusat biomedis dan teknologi dasar kesehatan. Media Litbang Kesehatan, 22(3), 138-143. 